\title{
Existing and new arrangements of pumped-hydro storage plants
}

4
Julian David Hunt ${ }^{a^{*}}$, Behnam Zakeri ${ }^{\mathrm{ab}}$, Rafael Lopes ${ }^{\mathrm{c}}$, Paulo Sérgio Franco Barbosa ${ }^{\mathrm{c}}$, Andreas Nascimento ${ }^{\mathrm{a}}$, Nivalde José de Castro $^{\mathrm{d}}$, Roberto Brandão ${ }^{\mathrm{c}}$, Paulo Schneider ${ }^{\mathrm{d}}$, Yoshihide Wada ${ }^{\mathrm{a}}$. a. International Institute for Applied Systems Analysis, Vienna, Austria.*hunt@iiasa.ac.at

b. Sustainable Energy Planning Research Group, Aalborg University, Copenhagen, Denmark

c. State University of Campinas, Campinas, Brazil

d. Federal University of Rio de Janeiro, Rio de Janeiro, Brazil

e. Federal University of Rio Grande do Sul, Porto Alegre, Brazil

The energy sector is undergoing substantial transition with the integration of intermittent and unpredictable renewable energy sources, such as wind and solar energy. These sources come with hourly, daily, seasonal and yearly variations; raising the need for short and long-term energy storage technologies to guarantee the smooth and secure supply of electricity. This paper critically reviews the existing types of pumped-hydro storage plants, highlighting the advantages and disadvantages of each configuration. We propose some innovative arrangements for pumped-hydro storage, which increases the possibility to find suitable locations for building large-scale reservoirs for long-term energy and water storage. Some of the proposed arrangements are compared in a case study for the upper Zambezi water basin, which has considerable water storage limitations due to its flat topography and arid climate. Results demonstrate that the proposed combined short and long-term cycles 
pumped-storage arrangement could be a viable solution for energy storage and reduce the cost for water storage to near zero.

Keywords: Electricity storage, Environmental impacts, Hydropower, Pumped-hydro storage, Sustainable energy, Variable renewable energy, Water management.

\section{Introduction}

33

The development of a sustainable future requires better management of natural resources. New resource management approaches and the UN's Sustainable Development Goals (SDGs) [1] have been focusing on the need to optimize interactions between water, energy and land, to provide society and the economy with the required resources at an affordable cost, while minimizing the adverse impacts on the environment $[2,3]$.

Water resources are essential for the development of society, industry, irrigation, transportation, recreation and hydropower generation. Water management can be a great challenge in dry regions, where there is a conflict in water demand between different sectors. Storage reservoirs play an important role to manage water resources across a basin and between time periods. However, storage reservoirs require appropriate geological formations that allow the reservoir level to vary significantly for storing a considerable amount of water. In plain regions, storage reservoirs can impose large land requirements, evaporation and capital costs to store small amounts of water and energy.

A reliable balance between energy supply and demand is facing more challenges with the integration of intermittent renewable energy sources such as wind and solar [4]. This has led to a growing demand for flexibility options such as energy storage [5]. These variable energy sources have hourly, daily and seasonal variations, which require back-up and 
balancing technologies to maintain a secure supply. Currently most pumped-hydro storage (PHS) plants only store energy in daily storage cycles, however, this might not be competitive in the future due to the reduction in battery costs [6]. It should be noted that both technologies have a negative energy balance (i.e., it consumes more energy that it produces). Other reviews on PHS types can be seen in [7]. And an high quality interactive map of the existing, under-construction and planned PHS projects can be seen in [8], as shown in Figure 1.
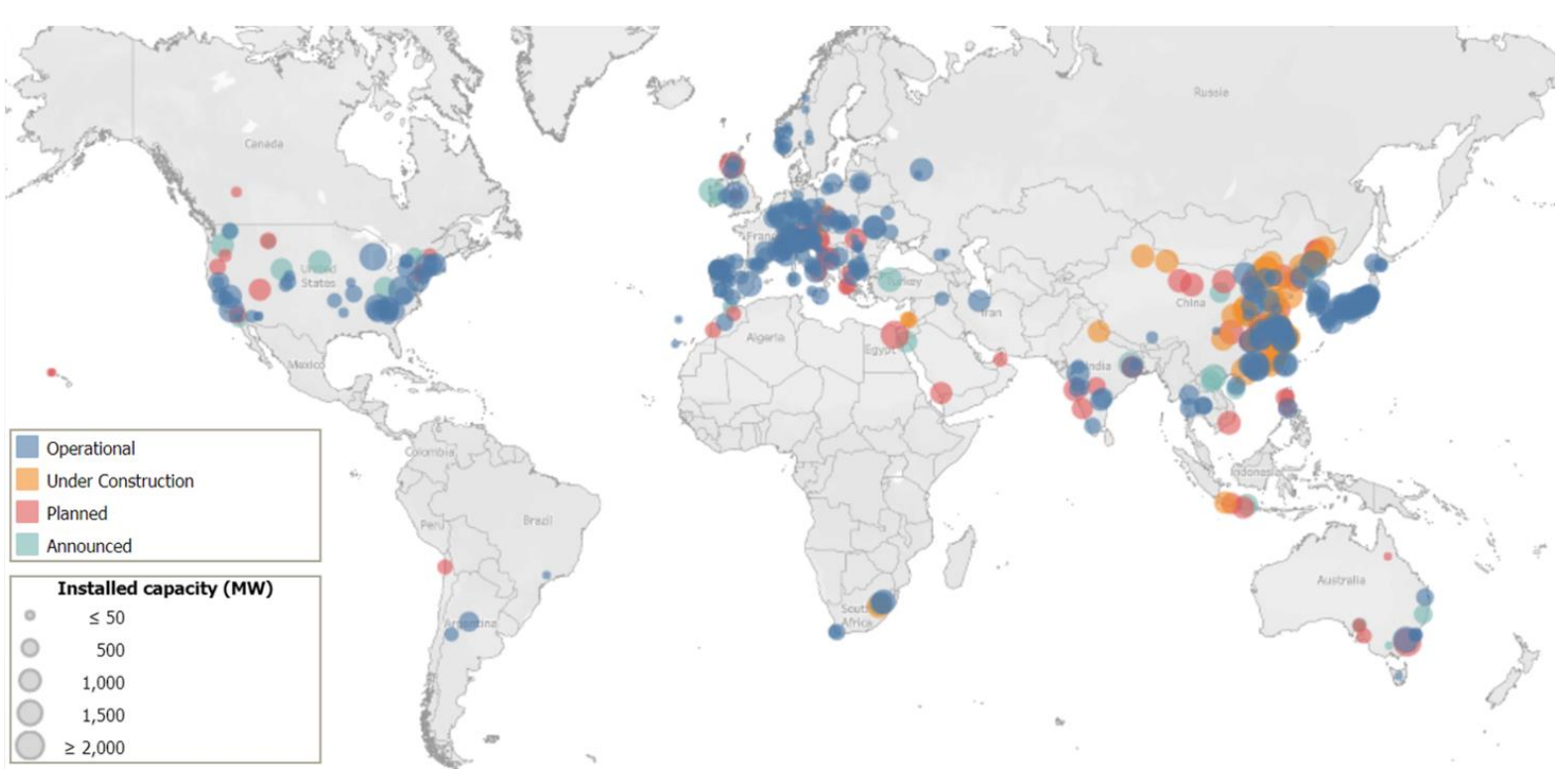

Figure 1: World map with all operational, under construction, and planned pumped-hydro storage plants [8].

An approach for optimizing the integration of water, energy and land resources, is the application of PHS for both short and long-term energy and water management. Instead of building storage reservoirs on main rivers, which causes large environmental impact and requires large land areas, a pump-station can store some of the water on the main river to a reservoir parallel to the river, usually in a tributary river [9]. These reservoirs would require considerably less land to store the same amount of water and energy because the upper reservoir water level would be able to vary much more than in typical conventional dams $[9,10]$. This approach for combining energy and water management with PHS plants has been 
applied in countries such as Austria, Switzerland, and Norway [11-20] for combined energy and water storage. However, there are only a limited number of arrangements that have been designed and built for combined water and energy storage with PHS, which are particularly not appropriate to locations with low topography variations.

This article presents the most common configurations of PHS and proposes new arrangements of PHS with the intent of increasing the possibilities for building large reservoirs with minimum impacts on society and the environment. The proposed arrangements will optimize hydropower generation in the dams downstream, minimize land requirement for water storage, reduce evaporation, and smoothen energy from intermittent renewable sources, among other applications. The superiority of the proposed pumped-hydro configurations compared to the existing methods will be examined through a case study on the Zambezi Basin. We apply a GIS-based potential assessment method to estimate the reservoir volume storage and the costs of the projects to locate suitable sites for the proposed arrangements. The results of this study will inform energy planners and decision makers with more optimal solutions for land-water-energy management.

This paper is divided into six sections. Section 2 reviews conventional types of PHS plants. Section 3 presents the concepts behind the proposed PHS arrangements in this paper. Section 4 presents the results of this paper, which consists of the proposal of PHS projects in the Zambezi river basin. Section 5 discusses the findings of this paper. Section 6 concludes the paper. 


\section{Classification of Existing Pumped-Hydro Storage Plants}

91

PHS plants can be categorized based on different criteria, which will be reviewed in this Section. These were divided into storage size, pump-turbine rotation speed, storage need, and existing PHS arrangements.

\subsection{Storage Size}

PHS plants can be divided according to storage size (see Table 1). The larger the upper reservoir storage size the higher the operational flexibility of the plant. A project with a large reservoir can provide the same services of a small reservoir and more, as explained as follows. Hourly pumped-hydro storage (HPHS) is used mainly to provide ancillary services such as frequency balancing, remove harmonics in the grid, provide backup power in case of disturbances in supply. HPHS can function on short circuit mode and they can make more than 100 reversions per day. An example of such plant is the Kops II in Austria [21,22].

Daily pumped-hydro storage (DPHS) is usually built for day-night energy arbitrage. This storage type is the most frequent PHS application today. The reduction in cost of batteries and the decentralization of power generation will probably reduce the importance of this type of pumped storage plant. An example of DPHS is Goldisthal in Germany [23,24].

Weekly pumped-hydro storage (WPHS) is usually built for storing energy from intermittent sources of energy such as wind and solar. This storage type has received an increased focus in recent years due to the ever-growing share of variable renewable energy. An example of WPHS is La Muela in Spain [25-28].

Seasonal pumped-hydro storage (SPHS) is further explained in this paper. SPHS is not widely employed in current energy systems, leaving this storage type with a large potential for the future. An example of SPHS is Limberg in Austria [14]. 
115 of energy and water beyond a yearlong horizon. Interest in this PHS type will increase due to

116 energy and water security needs in some countries. An example of this is Saurdal in Norway

$117[15,16]$.

Table 1: Different PHS cycles types for meeting energy needs [29].

\begin{tabular}{|c|c|c|}
\hline PHS Type & Operation Mode & Occasions when the PHS type operates \\
\hline \multirow{6}{*}{$\begin{array}{l}\text { Pluri-annual } \\
\text { Pumped- } \\
\text { Storage } \\
\text { (PAPHS) }\end{array}$} & \multirow{3}{*}{ Pump } & Annual surplus in hydroelectric generation. \\
\hline & & Annual fuel prices cheaper than average. \\
\hline & & Lower than average annual electricity demand. \\
\hline & \multirow{3}{*}{ Generation } & Annual deficit in hydroelectric generation. \\
\hline & & Annual fuel prices more expensive than average. \\
\hline & & Higher than average annual electricity demand. \\
\hline \multirow{8}{*}{$\begin{array}{l}\text { Seasonal } \\
\text { Pumped- } \\
\text { Storage } \\
\text { (SPHS) }\end{array}$} & \multirow{4}{*}{ Pump } & $\begin{array}{l}\text { Rainy seasons or ice melting seasons, with high } \\
\text { hydropower generation. }\end{array}$ \\
\hline & & Summer, with high solar power generation. \\
\hline & & Windy seasons, with high wind power generation. \\
\hline & & Low demand season, when electricity demand reduces. \\
\hline & \multirow{4}{*}{ Generation } & $\begin{array}{l}\text { Dry period or freezing winters, with low hydropower } \\
\text { generation. }\end{array}$ \\
\hline & & Winter, with low solar power generation. \\
\hline & & Not windy seasons, with low wind power generation. \\
\hline & & High demand season, when electricity demand increases. \\
\hline \multirow{6}{*}{$\begin{array}{l}\text { Weekly } \\
\text { Pumped- } \\
\text { Storage } \\
\text { (WPHS) }\end{array}$} & \multirow{3}{*}{ Pump } & During the weekends, when power demand reduces. \\
\hline & & Windy days, with high wind power generation. \\
\hline & & Sunny days, with high solar power generation. \\
\hline & \multirow{3}{*}{ Generation } & During weekdays, when power demand increases. \\
\hline & & Not windy days, with low wind power generation. \\
\hline & & Cloudy days, with low solar power generation. \\
\hline \multirow{4}{*}{$\begin{array}{l}\text { Daily } \\
\text { Pumped- } \\
\text { Storage } \\
\text { (DPHS) }\end{array}$} & \multirow{2}{*}{ Pump } & Night, when electricity demand reduces. \\
\hline & & Day, when there is solar power generation. \\
\hline & \multirow{2}{*}{ Generation } & Day, when electricity demand increases. \\
\hline & & Night, when there is no solar power generation. \\
\hline $\begin{array}{l}\text { Hourly } \\
\text { Pumped- } \\
\text { Storage } \\
\text { (HPHS) }\end{array}$ & $\begin{array}{l}\text { Pump \& } \\
\text { Generation }\end{array}$ & $\begin{array}{l}\text { Ancillary services: frequency control, remove harmonics } \\
\text { in the grid, provide backup power in case of } \\
\text { disturbances in supply. }\end{array}$ \\
\hline
\end{tabular}

119

121 conversion system (pump/turbine) and a tunnel Figure 2. The lower reservoir is meant for 
122 storing water and it may or may not have a large storage capacity. Typically, a month-long

123 storage capacity in the lower reservoir is enough to store water in days with intense rainfall

124 allowing the water in the main river to be pumped to the upper reservoir. The upper reservoir

125 should have a large storage capacity to take up a large part of the water from the main river

126 during the wet period, and possibly store water for use during droughts. Thus, most of the

127 water will be stored in the upper reservoir and the lower reservoir would control flow

128 fluctuation in the main river so that water will be available to be pumped to the upper reservoir.

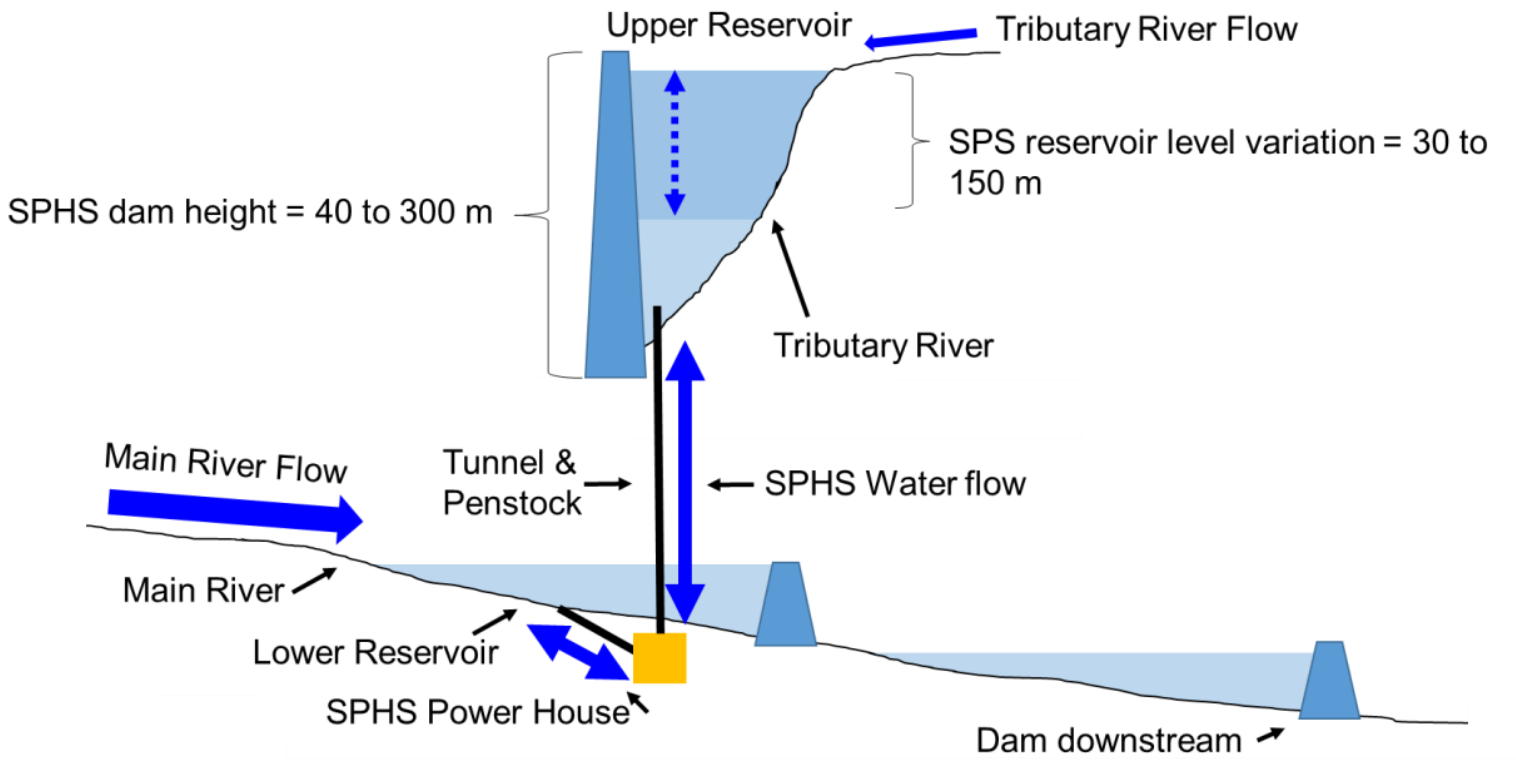

Figure 2: Diagram of a seasonal pumped-hydro storage plant. reducing the land requirement for water and energy storage. This low-flooded area and high-

134 level variation results in a low evaporation per stored water ratio. This makes SPHS suitable

135 for regions where evaporation has a large impact on water management. Locations where a $250 \mathrm{~m}$ high conventional dam with $200 \mathrm{~m}$ level variation can be constructed are not common

137 because the shores of major rivers are typically populated areas, with valuable infrastructure 138 and important economic activities. SPHS increases the possibility of building large reservoirs 
139 considerably as there are many more potential sites in small tributaries compared to

140 conventional dams in large rivers.

141 The water intake in a SPHS reservoir has two different origins. Firstly, water flows

142 from the tributary river directly to the SPHS reservoir. This can be due to precipitation and/or

143 ice melting. The other portion of the water in the SPHS reservoir comes from pumping water

144 from the lower reservoir. SPHS can be operated with a combination of daily, weekly and 145 yearly energy storage cycles and it may also be used to store water for water supply purposes.

146 It can be used, for peak generation, ancillary services, storing intermittent wind and solar

147 energy, hydropower optimization and water supply. The SPHS arrangement presented in this

148 section is limited to pumping water from a lower reservoir to an upper reservoir. The

149 following sections will present different arrangements where a single pump-turbine can be 150 applied in a variety of configurations to provide different services.

\subsection{Pump-Turbine types}

PHS plants can have turbines that operate with a fixed rotation speed or variable speed. Fixed-speed turbines have an invariable generation and pumping capacity. This is not ideal if the PHS plant is to be used to store and complement the electricity generated from variable energy sources, given its inflexibility in power output [30]. It allows the final generation potential to vary, which apart from storing energy from variable energy sources, has considerable advantages for controlling the frequency of the grid. In other words, a fixed

159 speed pump-turbine with a nominal $100 \mathrm{MW}$ capacity will only generate or pump $100 \mathrm{MW}$

160 of electricity under designed working conditions, while a variable speed pump-turbine will be 161 able to generate and pump with a capacity varying from around 60 to $100 \mathrm{MW}$. This allows 162 the pumped-turbine to store almost all excess wind generation in a system as shown in Figure 1633 for a system with five operating units. The fixed-speed turbine would not be able to store or 
generate electricity in the areas in colored in light blue. Variable speed pump-turbines cost approximately $30 \%$ more than fixed-speed alternatives and are not commonly used [31]. The final choice between fixed and variable speed turbines depends on techno-economic and demand aspects [32]. With the increase of intermittent renewables in the grid, variable speed turbines might become more common, which would reduce its price.

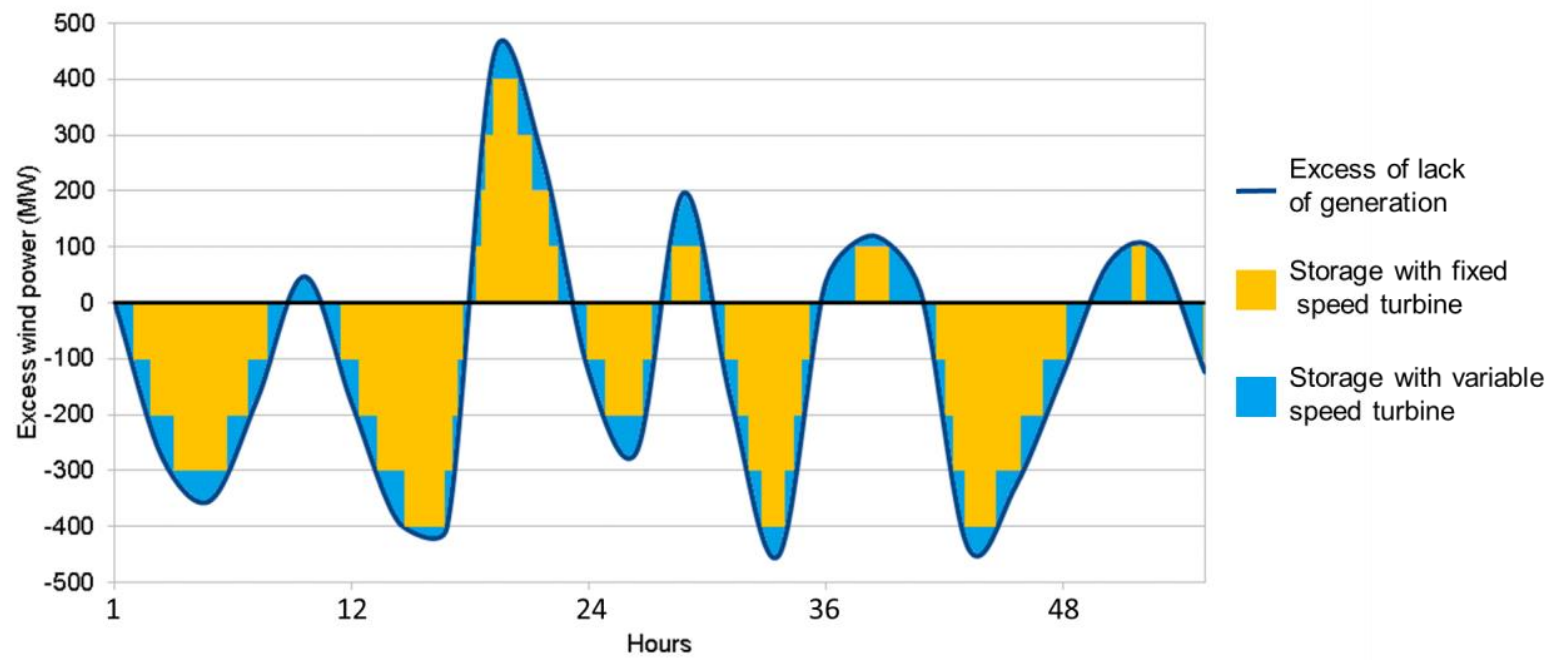

Figure 3: Operation of fixed and variable speed turbines.

The most relevant application of variable speed pump-turbines in this paper is the possibility of benefiting from a greater variation of the pumping/generation head. For example, if the maximum pumping head is $500 \mathrm{~m}$, the pump-turbine would operate at the maximum power of $100 \mathrm{MW}$ to maintain a reasonably high efficiency. When operating at low heads of $250 \mathrm{~m}$, the power of the turbines would have to reduce to, for example $60 \mathrm{MW}$. This would reduce the need for flow variation that passes through the pump-turbine when changing the operational head of the plant, maintaining a relatively high efficiency with large level variations $[33,34]$. Another advantage of a variable speed pump-turbine is its ability to operate efficiently even with large head variations.

Table 2 presents some PHS sites with pumping/generation head variations as high as 42.5\%. This paper assumes maximum pumping/generation head variation percentage of $50 \%$ 182 for the development of SPHS projects. This is a large value and could be reduced, however a 
183 reduction would affect some important design parameters, especially storage capacity and 184 operational flexibility of the proposed SPHS plants.

185 Another alternative to further increase the head variation of a SPHS plant is to operate 186 two pump-turbines in parallel when the pumping head is small and operate them in series 187 when the pumping head is high [35]. This is not ideal because the plant loses some of its 188 flexibility.

Table 2: PHS sites with high pumping/generation head variation [36,37].

\begin{tabular}{|c|c|c|c|c|c|c|c|c|}
\hline Project Name & Units & Head (m) & $\begin{array}{c}\text { Head } \\
\text { Variation (m) }\end{array}$ & $\begin{array}{c}\text { Variation } \\
\text { Percent }(\%)\end{array}$ & $\begin{array}{c}\text { Power } \\
(\mathbf{M W})\end{array}$ & Speed (rpm) & $\begin{array}{c}\text { Rotation } \\
\text { Speed }\end{array}$ & Country \\
\hline Nant de Drance & 6 & $250-390$ & 140 & 35.9 & 157 & $428.6+/-7 \%$ & Variable & Switzerland \\
\hline Linthal & 4 & $560-724$ & 164 & 22.7 & 250 & $500+/-6 \%$ & Variable & Switzerland \\
\hline Tehri & 4 & $127-221$ & 94 & 42.5 & 255 & $230.8+/-7.5 \%$ & Variable & India \\
\hline Limberg II & 2 & $273-432$ & 159 & 36.8 & 240 & 428.6 & Fixed & Austria \\
\hline
\end{tabular}

190

192 a Francis pump. In this setup the power electronics for variable frequency AC excitation

193 system and motor starter are no longer necessary, eliminating additional harmonic voltage or

194 current source in the grid. Coupling to Francis pump can be swiftly engaged and disengaged.

195 This enables shorter transition between power consumption mode and power generation

196 mode, as reversing the turbine rotation is not necessary. This is very suitable to response to

197 fluctuating power supply from wind and solar generation sources.

198

199

\subsection{Uses for PHS}

200

Another aspect that great influences PHS types is the requirements. PHS plants could

201 be used in combination with different needs. Some of the possible uses for PHS are explained

202 in Table 3. 


\begin{tabular}{|c|c|c|}
\hline Uses for PHS & Theme & Description \\
\hline Energy storage & & $\begin{array}{l}\text { - Energy storage for peak generation, intermittent renewable energies such } \\
\text { as wind and solar, optimize electricity transmission, among others. }\end{array}$ \\
\hline $\begin{array}{l}\text { Highly seasonal } \\
\text { hydropower generation }\end{array}$ & & $\begin{array}{l}\text { - Increase water and energy storage in water basins to regulate the river } \\
\text { flow and increase hydropower generation. } \\
\text { - Store excess water during periods of high hydropower generation and } \\
\text { reduce spillage. }\end{array}$ \\
\hline $\begin{array}{l}\text { Goal for } \mathrm{CO}_{2} \text { emissions } \\
\text { reduction }\end{array}$ & & $\begin{array}{l}\text { - Hydropower, solar and wind generation usually do not have the same } \\
\text { seasonal generation profile as the demand for electricity. Natural Gas is } \\
\text { an option for flexible electricity generation, however, it is a fossil fuel- } \\
\text { based source of energy and emits } \mathrm{CO}_{2} \text {. A seasonal storage option should } \\
\text { be considered by countries that intends to considerably reduce } \mathrm{CO}_{2} \\
\text { emissions. }\end{array}$ \\
\hline $\begin{array}{l}\text { Seasonal energy supply } \\
\text { and demand variations }\end{array}$ & Energy & $\begin{array}{l}\text { - Countries in high latitudes have a very seasonal solar power generation } \\
\text { profile. Seasonal storage allows using the energy stored in the summer } \\
\text { during the winter, when there is lower solar generation. } \\
\text { - Countries in mid and high latitudes tend to have a seasonal electricity } \\
\text { demand profile, consuming more electricity summer for cooling and } \\
\text { during the winter for heating purposes, respectively. Typically, the peak } \\
\text { national grid demand can be two to three times as high as the minimum } \\
\text { demand. } \\
\text { - With the electrification of the heating sector in countries at high latitude, } \\
\text { the demand of electricity during the winter will increase even further. }\end{array}$ \\
\hline Energy security & & $\begin{array}{l}\text { - Reduction in fluctuation of electricity prices with fossil fuel prices and } \\
\text { supply. } \\
\text { - Reduction in fluctuation of electricity prices with renewable energy } \\
\text { availability, especially hydropower. } \\
\text { - Reduction in fluctuation of electricity prices with the demand for } \\
\text { electricity. }\end{array}$ \\
\hline Water Storage & \multirow{6}{*}{ Water } & $\begin{array}{l}\text { - PHS plants can store water on higher ground away from the river, in } \\
\text { cases where along the river is infeasible or due to high evaporation rates. }\end{array}$ \\
\hline $\begin{array}{l}\text { High storage reservoir } \\
\text { sedimentation }\end{array}$ & & $\begin{array}{l}\text { - PHS projects have much smaller sedimentation rates than conventional } \\
\text { dams due to the small catchment area. }\end{array}$ \\
\hline $\begin{array}{l}\text { Better water quality } \\
\text { control }\end{array}$ & & $\begin{array}{l}\text { - Storing the water parallel to the river, allows for a better control of the } \\
\text { water quality in the reservoir. As it would not be directly affected by the } \\
\text { fluctuations in water quality in the main river. }\end{array}$ \\
\hline Flood control & & $\begin{array}{l}\text { - PHS plants can be used in combination with conventional flood control } \\
\text { mechanisms to improve their efficacy. }\end{array}$ \\
\hline $\begin{array}{l}\text { Transport with } \\
\text { waterways }\end{array}$ & & $\begin{array}{l}\text { - PHS plant channels could be also used for transport in waterways, } \\
\text { combining the transport of water and goods. Additionally, the } \\
\text { improvement in water management resulted from a SPHS plant would } \\
\text { reduce the changes that a waterway runs out of water. }\end{array}$ \\
\hline Inter-basin Transfer & & $\begin{array}{l}\text { - PHS projects can be combined with an inter-basin transfer project to } \\
\text { increase the water security of a region or provide balancing between } \\
\text { watersheds.PHS plants used for inter-basin transfer usually have longer } \\
\text { tunnels or use the upper reservoir as a canal to facilitate water basin } \\
\text { transposition, e.g., Snowy Mountain scheme in Australia [38] and the } \\
\text { Grand Coulee dam in the USA [39,40]. }\end{array}$ \\
\hline
\end{tabular}




\begin{tabular}{|c|c|c|}
\hline Low evaporation & & $\begin{array}{l}\text { - In some cases, PHS are used for water storage due to the lower } \\
\text { evaporation in these plants [41]. }\end{array}$ \\
\hline Water security & & $\begin{array}{l}\text { - Increase the water storage capacity in regions where conventional storage } \\
\text { reservoirs are not appropriate. }\end{array}$ \\
\hline $\begin{array}{l}\text { Lower environmental } \\
\text { and social impacts }\end{array}$ & Environment & $\begin{array}{l}\text { - Damming a major river for storage would affect a higher environmental } \\
\text { and social impact than damming a small tributary river. SPHS allows } \\
\text { water storage without fragmenting the ecosystem of a main river. }\end{array}$ \\
\hline
\end{tabular}

205

206

$207 \quad$ 2.4 Existing pumped-hydro storage arrangements.

The most well-known PHS arrangements are open-loop, closed-loop and pump-back

209 storage. Open-loop consists of a PHS plant where there is a significant stream of water to the

210 upper or the lower reservoir (Figure 4 (a)). In this setup the operation of the pump-turbine

211 may interfere with the river flow and this should be carefully cared for. In order to minimize

212 the impact on the river flow, PHS schemes usually make use of existing hydropower dams as

213 the lower reservoir. In cases where the lower reservoir is an existing dam, the powerhouse

214 can be built downstream the dam. This way, the powerhouse will not require to be excavated

215 as the head of the dam already increases the pressure in the powerhouse, like Seneca PHS in

216 the USA [42] as shown in Figure 4 (a).

217 Close-loop PHS consists of an upper and lower reservoir far from a large water source

218 and, thus, with a limited water input into the system (Figure 4 (b)). These systems can be

219 implemented in small artificial lakes, filled either by the precipitation of its limited catchment

220 area or on water brought from a different location $[43,44]$. The evironemental impact of

221 closed loop PHS plants is usually smaller than open-loop plants. however they are usually

222 limited to daily or weekly storage cycles. An example of a close-loop project is the Marmora

223 PHS in Canada [45].

Pump-back storage consists of installing pump-turbine in hydropower dams wherever

225 there is anoter reservoir immediately downstream. This allows the water flow back and 
226 forward between the two reservoirs [46] (Figure 4 (c)). This arrangement increases flexibility

227 and operational range as the pump-turbines can be used for both hydropower conventional

228 generation and storage. For example, in case of a drought, conventional hydropower

229 generation will be reduced, but the plant can still be used as pumped storage. The head in

230 pump-back storage plants is usually low. However, the system is viable as long tunnels are

231 not required. In Japan, a number of dams were built with reversible turbines [47]. This is due

232 to the historic dependence of Japan on nuclear energy, an inflexible source of generation,

233 which creates the need for daily energy storage. The pump-back plants can also be used as

234 part of a water supply solution. The precipitation downstream Japanese rivers can be pumped

235 upstream by pump-back storage plants to be stored on the head of the river for later use.

236 Without a pump-back solution, some of the water would be discharged to the sea. An

237 example of such scheme is Kannagawa in Japan [48]. 


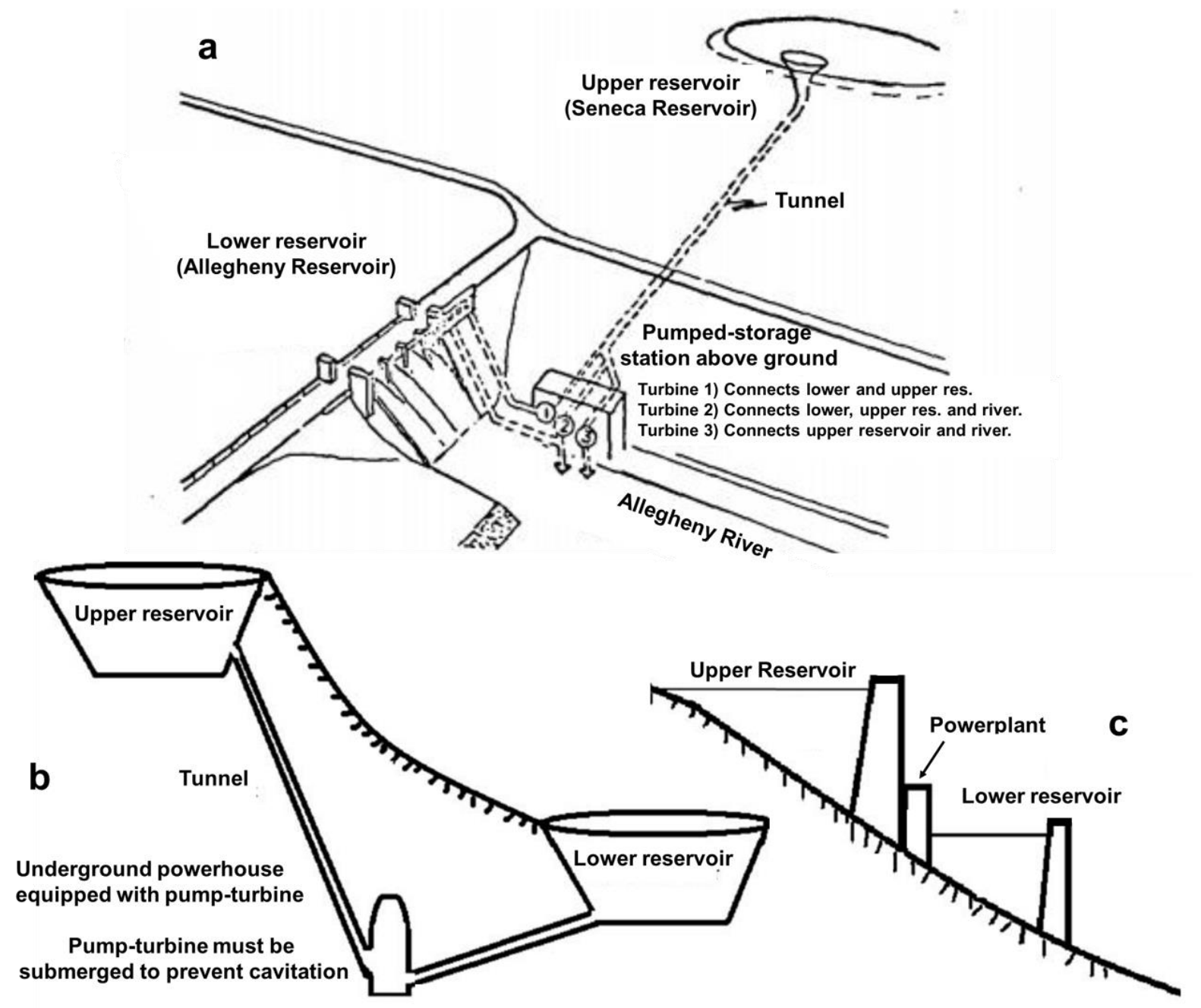

Figure 4: Three types of PHS arrangements. (a) Open-loop PHS plant with no need for excavation [29], (b) closed-loop PHS with no considerable inflow in the upper or lower reservoir [47], (c) pump-back PHS with no need for excavation [47]. PHS can provide energy and water storage combined with desalination and demand

243 side management as a very effective way to optimize the energy and water supply in an 244 island, especially in the presence of variable energy sources in the system. An example of this 245 integration happens in the Soria-Chira plant in the Canary Islands [49,50]. Other less 246 common configurations of PHS include underground PHS [51-54], decommissioned open pit 247 mines PHS [55,56], seawater PHS [57-59], gravity-based cylindrical systems [60,61], 
248 offshore water storage at sea [62], and storage of water and energy inside wind turbine towers $249[63]$.

251 dam the river (Figure 5), thus, reducing social and environmental impacts [37,64]. Run-of252 the-River SPHS are used to extract continuous amounts of water from the river during 253 periods of high river flowrate and return continuous amounts of water to the river during periods with low river flowrate. The constant return of water intends to reduce the impact of river flow variations, which impacts the ecosystem in and around the river. The lower reservoir, which is not on the main river, is used as a standard PHS lower reservoir. In this way, the same pump-turbines can be used both to regulate the river and as an energy storage solution. The high head pump-turbines can only move water from the lower reservoir or from the river to the upper reservoir and vice-versa. There might also be the need of a low head pump-turbine to pump water from the river to the lower reservoir, to keep the river flow constant. An example of run-of-the-river PHS is Malta in Austria [14].

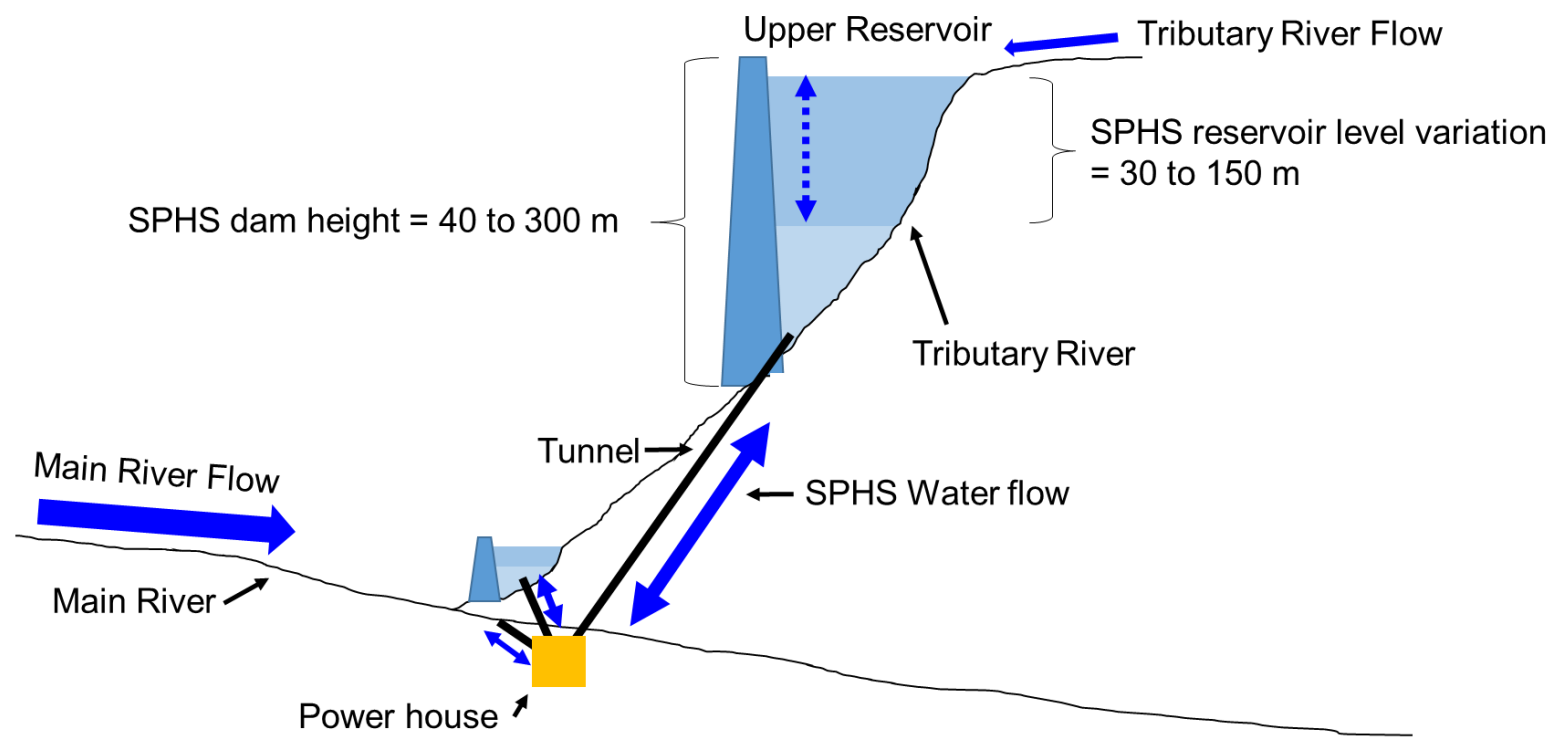

Figure 5: Run-of-the-river seasonal pumped-hydro storage with a large upper reservoir and a small lower reservoir. 


\section{Methodology: Proposed Pumped-Hydro Storage Arrangements}

This section presents some PHS arrangements that have not yet been implemented.

They could be considered for specific water and energy storage services on locations with low topographical variations and low water availability.

270

3.1 Combined Short and Long-Term Cycle Seasonal Pumped-Hydro Storage

\section{(CCSPHS)} in order to increase water and energy storage capacity in the main reservoir in locations where topography does not allow a more conventional setup.

As shown in Table 2, head variation in conventional PHS setups can be designed to vary up to $50 \%$. If the level variation of an individual turbine is higher than $50 \%$, the efficiency will be considerably affected. It would be possible to to build two sets of turbines with different designs to allow a head variations greather than $50 \%$. However, this would considerably impact the feasibility of the project.

In order to solve this head variation limitation and increase the designed reservoir storage capacity, this paper proposes new SPHS arrangements with three reservoirs. In these arrangements the water can be shifted around the three reservoirs and fulfil short-term energy storage needs and long-term energy and water storage needs. These arrangements are further explained in the paragraphs below.

The SPHS arrangement presented in Figure 6 (a) consists of a small lower reservoir in

287 the river, a large intermediate reservoir and a small upper reservoir. As in Section 2.3.1, water

288 flows from the lower and intermediate reservoir to the upper reservoir and vice-versa. 289 However, it would be difficult and expensive to operate a pumping system from the lower to 
290 the intermediate reservoir due to the large head variation, as explained above. Thus, this 291 arrangement would only work if short and long-energy storage needs are combined. For 292 example, water pumped from the river to the upper reservoir at night is released during the 293 day to the intermediate reservoir as part of a daily energy storage cycle. During the day water 294 from the upper reservoir flows to the intermediate reservoir generating electricity while at the 295 same time storing water in the seasonal reservoir. The large intermediate reservoir can have a 296 large head variation given that the water used to fill up this reservoir come from the upper 297 reservoir. The combination of the two cycles (short and long-term) is important because a 298 pump-turbine system would not the able to pump water from the lower reservoir to the 299 intermediate reservoir due to the pump-turbine limitation in head variation. This arrangement 300 is proposed for a location where the topography does not allow the construction of storage 301 reservoirs and there is a need for short and long-term energy or water storage, for example, in the Amazon and upper Zambezi basins. Another possibility is to build two medium-sized reservoirs, as shown in Figure 6 (b).

304 The operation would be similar to the presented in Figure 6 (a). Given that the storage is split 305 in two medium-sized reservoirs, the overall water storage would be smaller and the social and 306 environement impacts may be larger. However, this arrangement can be the most cost307 effective option for a specific case, depending on the topography. It also has a greater 308 operation flexibility, as the two reservoirs will have enough water for long-term storage 309 cycles regardless of the river flow. 


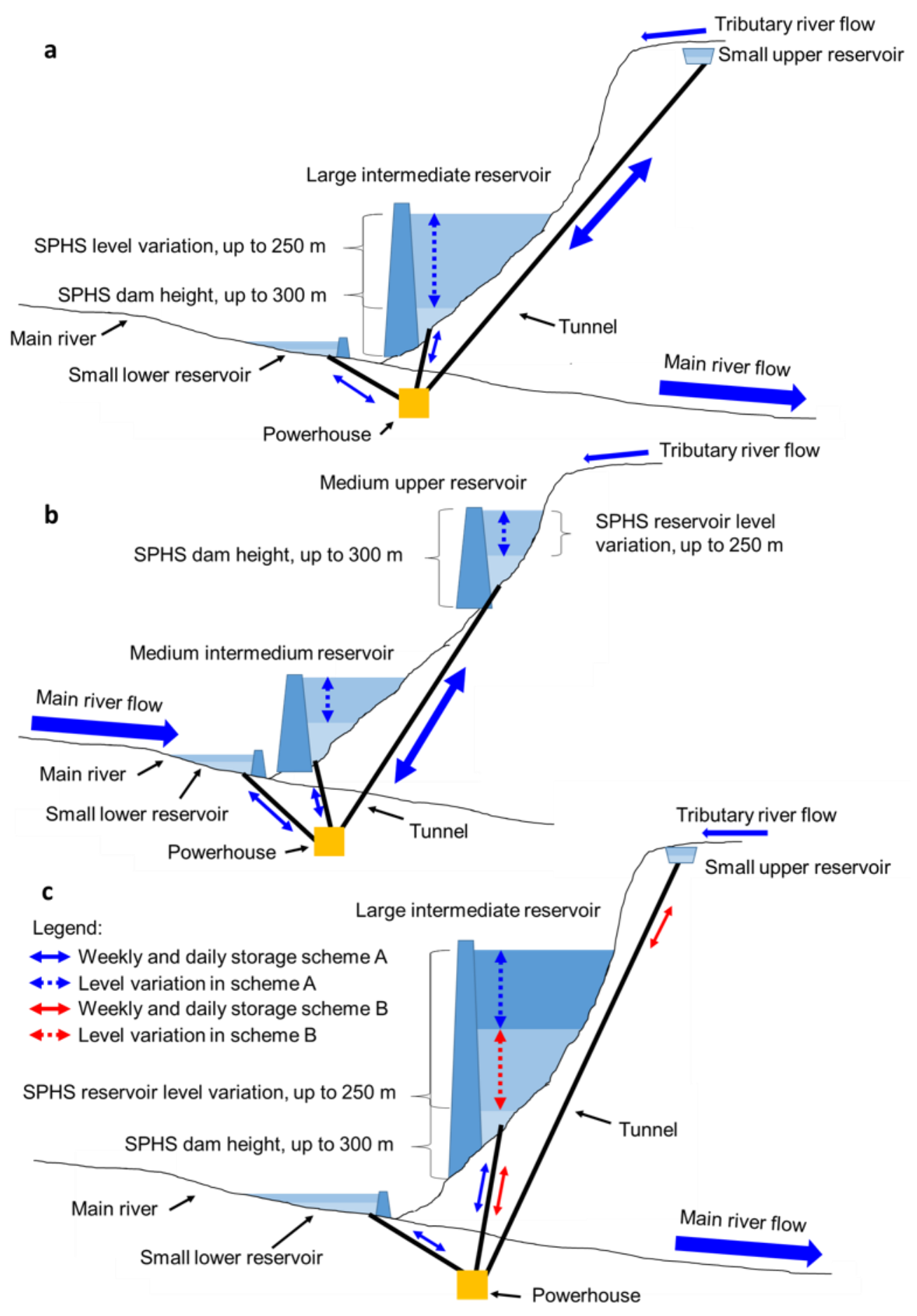

311 Figure 6: SPHS arrangements for combined short and long-term storage with (a) small upper

312 reservoir and a large intermediate reservoir, (b) medium upper reservoir and medium intermediate reservoir, (c) intermediate reservoir divided in two sections.

Figure 6 (c) presents the arrangement that allows the highest water level variation in

315 flat topography regions, which in turn contributes to a smaller land requirement in relation to 
316 water storage capacity. It would also reduce evaporation. In this arrangement, the 317 intermediate reservoir would be filled up with water from the lower reservoir when the

318 intermediate reservoir level is high enough, and it would be filled from the upper reservoir, 319 when the intermediate reservoir level is low. This change in operation from the lower to the 320 upper reservoir is important because the head of the pump-turbine cannot vary with all the 321 reservoirs level variation as it is limited to, for example to $50 \%$ of the maximum head. The operation in Figure 6 (c) divides the maximum head variation of the pump-turbine in almost half. In this arrangement, the minimum designed pumping head capacity is higher than in Figure 6 (a), which reduces tunnel costs.

The arrangements presented above allow the pumping head and reservoirs to have a head variation larger than $50 \%$. This is particularly interesting to store large amounts of energy and water in locations where the topography does not permit the construction of conventional SPHS plants.

\subsection{Combined Hydropower and Pumped-Hydro Storage (CHPHS)}

A CHPHS plant can be used for hydropower generation or for energy storage (Figure

7 (a)). The lower reservoir is built on the main river and the powerhouse is built downstream of the dam. This arrangement does not require excavation, as the water level in the river dam already maintains the required pressure on the pump-turbine to prevent cavitation. This considerably reduces project costs, especially if the plant has a low generating head [65]. This arrangement is similar to the one in the Seneca PHS [42] (Figure 4 (c)). It offers flexibility for the operation of the system, making it possible to decide if the dam generates hydropower, e.g., during periods of large river flow, or if the pumped-hydro storage is to be used to help manage the grid (energy storage) or to increase river flow during dry periods. In order for these arrangements to work properly, the height of the reservoirs must match each 
341 other as shown in Figure 7, where ' $\mathrm{X}$ ' represents the height of the reservoir. Table 4 presents

342 different pumping/generation head configurations of CHPHS plants.

a

$\longrightarrow$ Water flow in scheme $A$

$\leftrightarrow$ Water flow in scheme B

$\leftrightarrow$ Level variation in scheme $B$

Main river flow

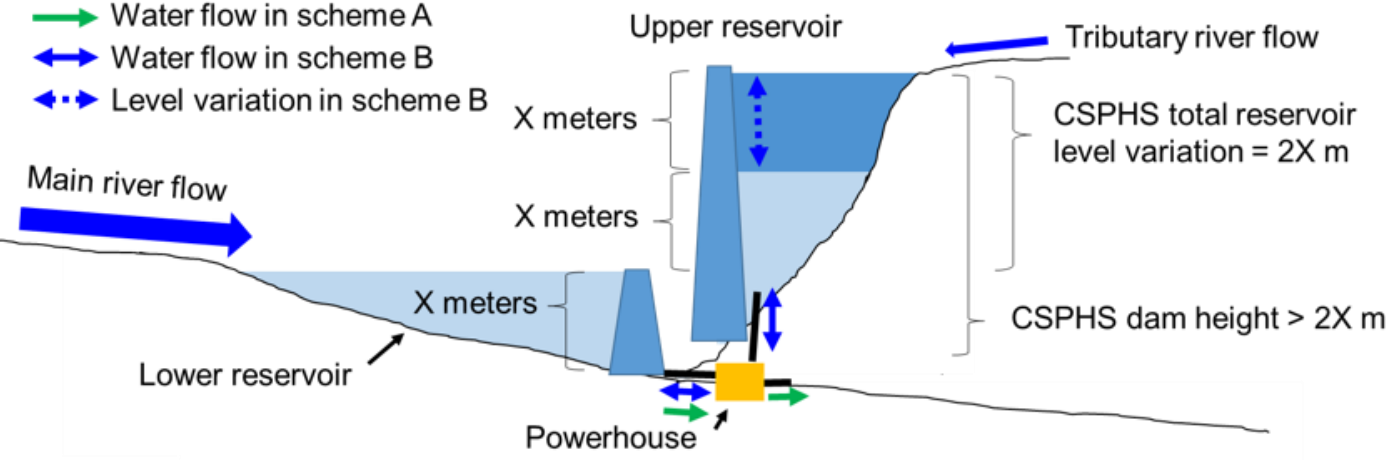

b

$\longleftrightarrow$ Water flow in scheme A

$\longleftrightarrow$ Water flow in scheme B

$\leftrightarrow$ Level variation in scheme B

$\leftrightarrow$ Water flow in scheme C

$\leftrightarrow$ Level variation in scheme C

\section{Main river flow}

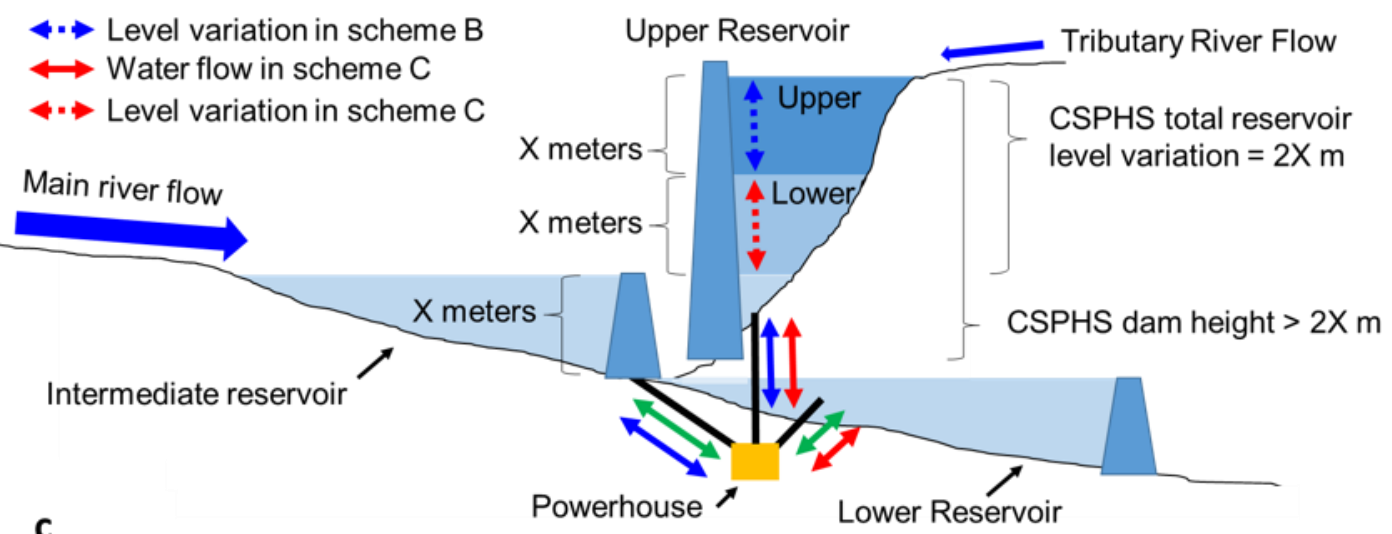

C

$\leftrightarrow$ Water flow in Scheme A

$\leftrightarrow$ Water flow in Scheme B

$\leftrightarrow$ Level variation in Scheme B

$\leftrightarrow$ Water flow in Scheme C

$\leftrightarrow$ Level variation in Scheme C

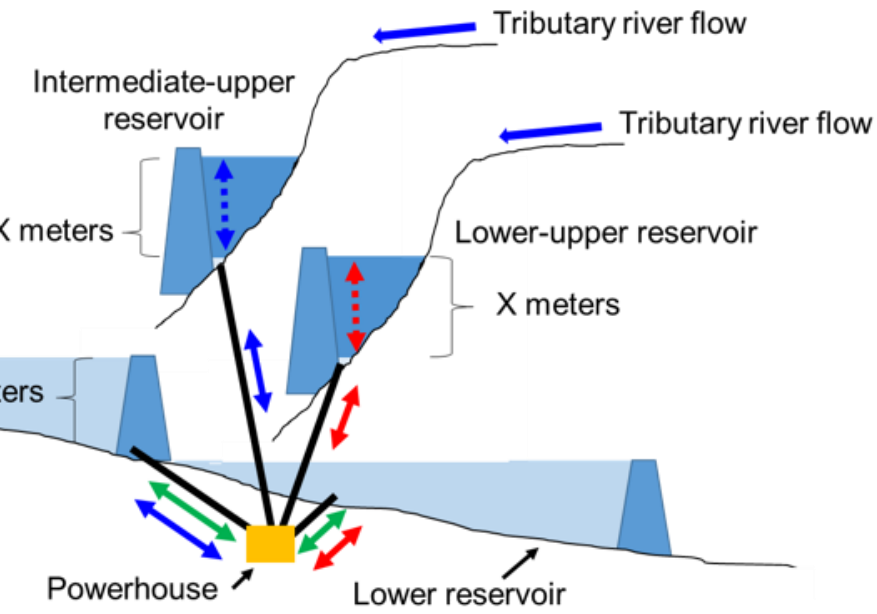

$344 \quad$ Figure 7: Combined hydropower and pumped-hydro storage (CHPHS) arrangement. (a)

345 Without lower reservoir and without the need for powerhouse excavation. (b) With lower 

connected.

Table 4: Different configurations for combined hydropower and PHS plants. Possible values for ' $\mathrm{X}$ ' in Figure 7.

\begin{tabular}{|c|c|c|c|}
\hline $\begin{array}{c}\text { Intermediate Reservoir } \\
\text { Generation Head (m) }\end{array}$ & $\begin{array}{c}\text { Turbine } \\
\text { pumping/generati } \\
\text { on head variation } \\
(\mathbf{m})\end{array}$ & $\begin{array}{c}\text { Upper Reservoir } \\
\text { maximum } \\
\text { level variation } \\
(\mathbf{m})\end{array}$ & $\begin{array}{c}\text { CHPHS dam height } \\
(\mathbf{m})\end{array}$ \\
\hline 30 & $30-60$ & 60 & $70-90$ \\
\hline 50 & $50-100$ & 100 & $110-150$ \\
\hline 70 & $70-140$ & 140 & $150-210$ \\
\hline 100 & $100-200$ & 200 & $210-300$ \\
\hline
\end{tabular}
lower reservoir to the system. This would result in three or more reservoirs instead of two. These can be the upper, intermediate and lower reservoirs, as shown in Figure 7 (b) for a three-reservoir case. This arrangement consists of two dams built in the main river and a larger reservoir dam on a tributary river. These reservoirs are connected via tunnels to the same pump/turbines, providing flexibility to operate at a variety of different modes. The upper reservoir should store large amount of water and energy, similar to SPHS plants. If there is only need to store short-term energy, a pump-back solution would be much more practical and cheaper.

The arrangements in Figure 7 (b) and (c) can operate in three different ways detailed in Table 5. In the Scheme A, the pump-turbine operates close to the lowest generation head similarly to a pump-back power plant allowing water to flow from the intermediate reservoir

364 into the lower reservoir and vice-versa. The Scheme B is similar to a SPHS plant. Water is pumped from the intermittent reservoir into the upper section of the upper reservoir for storage and vice-versa. It should be noted that generation and pumping cannot happen 
367 between the upper section of the upper reservoir and the intermidiate reservoir, as the head

368 variation would be too low. The Scheme C also operates similarly to a SPHS plant; however,

369 the water flows from the lower reservoir into the lower section of the upper reservoir. Note

370 that this scheme can only operate if the upper reservoir is in the lower section. Similarly,

371 Scheme B can only operate if the upper reservoir is in the upper section, as the pumping head

372 would be too small for an efficient operation.

373 Table 5: Different operational approaches for multi reservoirs combined hydropower and pumped-hydro storage plant.

\begin{tabular}{|c|c|c|c|c|}
\hline $\begin{array}{c}\text { Operational } \\
\text { Scheme }\end{array}$ & Main Purpose & $\begin{array}{l}\text { Operation } \\
\text { Mode }\end{array}$ & Water from & Water to \\
\hline \multirow{2}{*}{$\mathbf{A}$} & \multirow{2}{*}{ Pump Back Storage } & Generation & Intermediate Reservoir & Lower Reservoir \\
\hline & & Pump & Lower Reservoir & Intermediate Reservoir \\
\hline \multirow{2}{*}{ B } & \multirow{2}{*}{$\begin{array}{c}\text { Water and Energy } \\
\text { Storage }\end{array}$} & Generation & $\begin{array}{l}\text { Upper Reservoir, } \\
\text { Upper Section }\end{array}$ & Intermediate Reservoir \\
\hline & & Pump & Intermediate Reservoir & $\begin{array}{l}\text { Upper Reservoir, } \\
\text { Upper Section }\end{array}$ \\
\hline \multirow{2}{*}{$\mathbf{C}$} & \multirow{2}{*}{$\begin{array}{c}\text { Water and Energy } \\
\text { Storage }\end{array}$} & Generation & $\begin{array}{l}\text { Upper Reservoir, } \\
\text { Lower Section }\end{array}$ & Lower Reservoir \\
\hline & & Pump & Lower Reservoir & $\begin{array}{l}\text { Upper Reservoir, } \\
\text { Lower Section }\end{array}$ \\
\hline
\end{tabular}

375

377 system, as such, increasing the amount of available water to be stored in the upper reservoir.

378 The lower the dam is in a river basin the bigger its catchment area and, usually, the higher its

379 flow rate. Thus, a lower reservoir would increase the availability of water for storage.

380 However, this arrangement could be built without a lower reservoir. The lower reservoir

381 might not be required, if it would not considerably increase the catchment area of the plant, or

382 if the flow at the intermediate reservoir is large enough, or if it is not viable due to economic,

383 social or environmental reasons. In this case, Scheme C can still be operational the dam 384 downstream outlet can be designed to work as a small lower reservoir and Scheme A can 
operate at the same time as Scheme B so that the lower section of the upper reservoir can fill up.

To analyze the proposed configurations, a pumped-storage GIS siting module have been developed by the authors in Python to find PHS project locations. The Shuttle Radar Topography Mission (SRTM) 90m Digital Elevation data is used in the module [66]. The reservoir locations and size have been identified with the objective of storing around $50 \%$ of the total hydrological available flow. The methodology applied to compare the three different SPHS approaches is based on the hydrological flow obtained from [67], the design of the PHS components taken from [68] and the cost estimations from [65]. Mode details on the methodology applied in this module can be found in [69].

\section{Zambezi Basin Case-Study: Comparing Proposed Pumped-Hydro}

\section{Storage Arrangements}

This section examines different arrangements proposed for PHS on the Zambezi basin. The best examples for SPHS, CCSPHS and CHPHS identified in the Zambezi upper basin are shown in Figure 8. Most projects are proposed in the upper Zambezi basin, upstream the Victorian Falls, which have practically no storage reservoirs due to its low topography and high evaporation rates. The existing Kariba and Cahora Bassa conventional reservoir dams (CRD) are also included in the figure. The details of each project are shown in Table 6. 


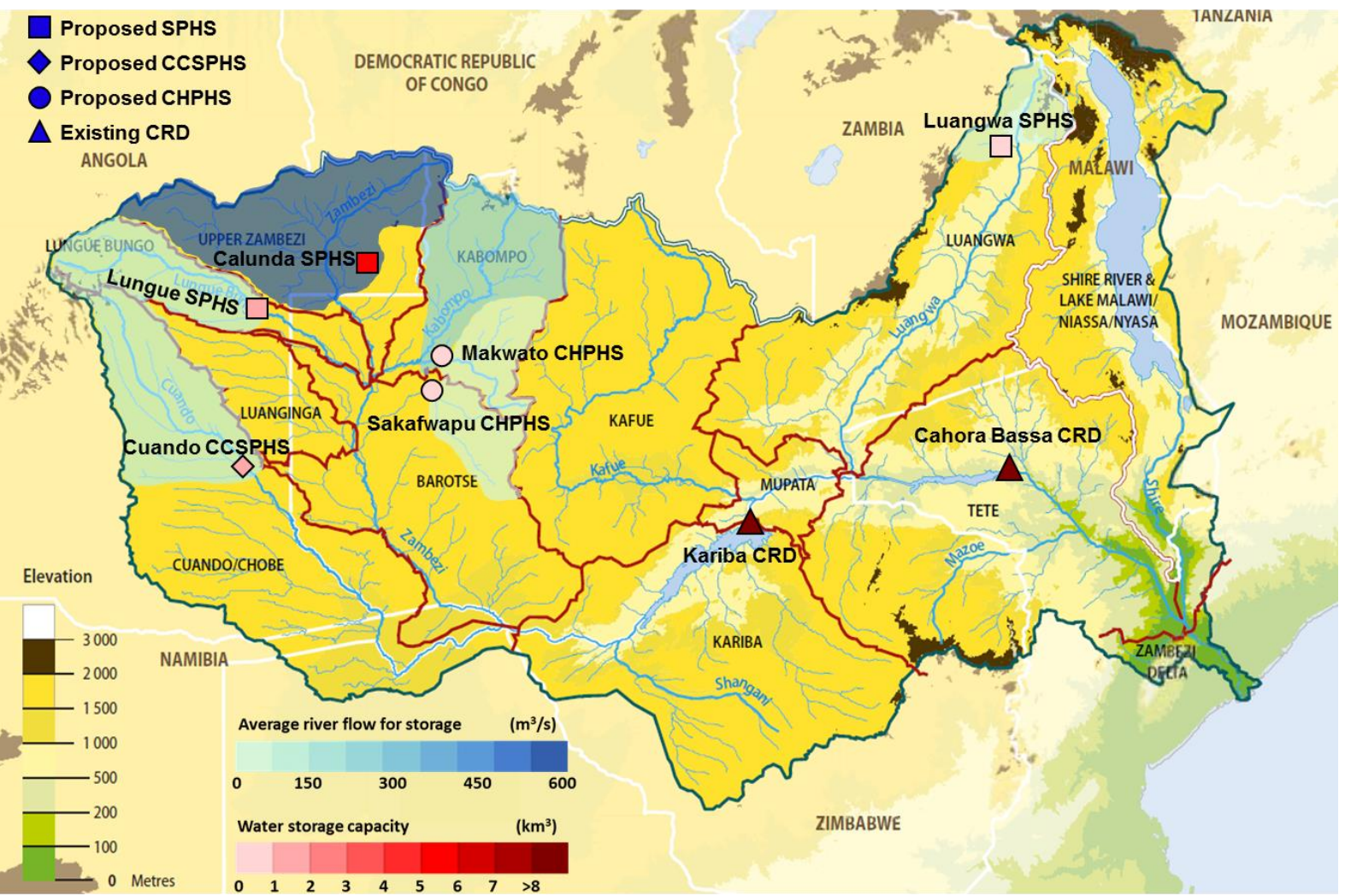

Figure 8: Different arrangements of PHS plants proposed for the Zambezi river basin, with average river flow and water storage capacity.

Table 6: Description of proposed PHS plants.

\begin{tabular}{|l|c|c|c|c|c|c|}
\hline Details & Lungue & Cuando & Calunda & Sakafwapu & Mukwato & Luangwa \\
\hline Storage Type & SPHS & CCSPHS & SPHS & CHPHS & CHPHS & SPHS \\
\hline Maximum level (m) & 1180 & 1135 & 1200 & 1140 & 1145 & 955 \\
\hline Minimum level (m) & 1150 & 1100 & 1160 & 1100 & 1100 & 905 \\
\hline Level variation (m) & 30 & 35 & 40 & 40 & 45 & 50 \\
\hline Downstream level (m) & 1120 & 1060 & 1055 & 1085 & 1085 & 680 \\
\hline Dam height (m) & 40 & 55 & 70 & 60 & 60 & 70 \\
\hline Dam length (km) & 4 & 2 & 4 & 2 & 4 & 1 \\
\hline Tube (km) & 10 & 6 & 23 & 8 & 9 & 12 \\
\hline Maximum Flooded area $\left(\mathbf{k m}^{\mathbf{2}}\right)$ & 120 & 57.5 & 314.5 & 39 & 92 & 44.6 \\
\hline Minimum Flooded area $\left(\mathbf{k m}^{\mathbf{2}}\right)$ & 40 & 32 & 75 & 30 & 21 & 7 \\
\hline Flooded area variation ratio & 3 & 1.8 & 4.2 & 1.3 & 4.35 & 6.4 \\
\hline Total flooded area $\left(\mathbf{k m}^{\mathbf{2}}\right)$ & 130 & 67 & 345 & 69 & 160 & 54 \\
\hline
\end{tabular}




\begin{tabular}{|c|c|c|c|c|c|c|}
\hline Useful stored volume $\left(\mathrm{km}^{3}\right)$ & 1.80 & 1.21 & 5.03 & 0.94 & 2.07 & 0.89 \\
\hline Catchment Area $\left(\mathbf{k m}^{2}\right)$ & 21536 & 30509 & 73054 & 19023 & 19741 & 16152 \\
\hline Average flow $\left(\mathrm{m}^{3} / \mathrm{s}\right)$ & 0.9 & 1.27 & 9.59 & 0.59 & 0.82 & 0.84 \\
\hline Storage / $50 \%$ annual flow ratio & 92 & 79 & 597 & 37 & 246 & 52 \\
\hline $\begin{array}{l}\text { Sub-basin drought water availability } \\
\left(\mathbf{m}^{3} / \mathbf{s}\right)[70]\end{array}$ & 15 & 12 & 40 & 200 & 65 & 0 \\
\hline Wind speed $(\mathrm{m} / \mathrm{s})[23]$ & 5.7 & 7,0 & 5.5 & 6.9 & 6.7 & 7.8 \\
\hline Solar Irradiation $\left(\mathrm{kWh} / \mathrm{m}^{2}\right)[24]$ & 2050 & 2100 & 2050 & 2050 & 2100 & 2300 \\
\hline
\end{tabular}

Even though water storage with low evaporation is the main objective of the proposed

412 plants, to make the construction of the plant economically feasible and socially acceptable,

413 energy storage services are also taken into account for grid management. Given the need of

414 energy to store water with pumped-hydro storage, it is important to analyze the existing

415 renewable energy potential of the region. The average wind speed across the river basin is

416 small. There are only a few locations with average wind speeds higher than $7 \mathrm{~m} / \mathrm{s}$ (Figure 9

417 (a)). However, the region has solar power potential reaching a yearly average of 2300

$418 \mathrm{kWh} / \mathrm{m}^{2}$ (Figure 9 (b)). Solar power could be used to pump the water in PHS plants and PHS

419 could reduce the intermittence of solar power generation. 

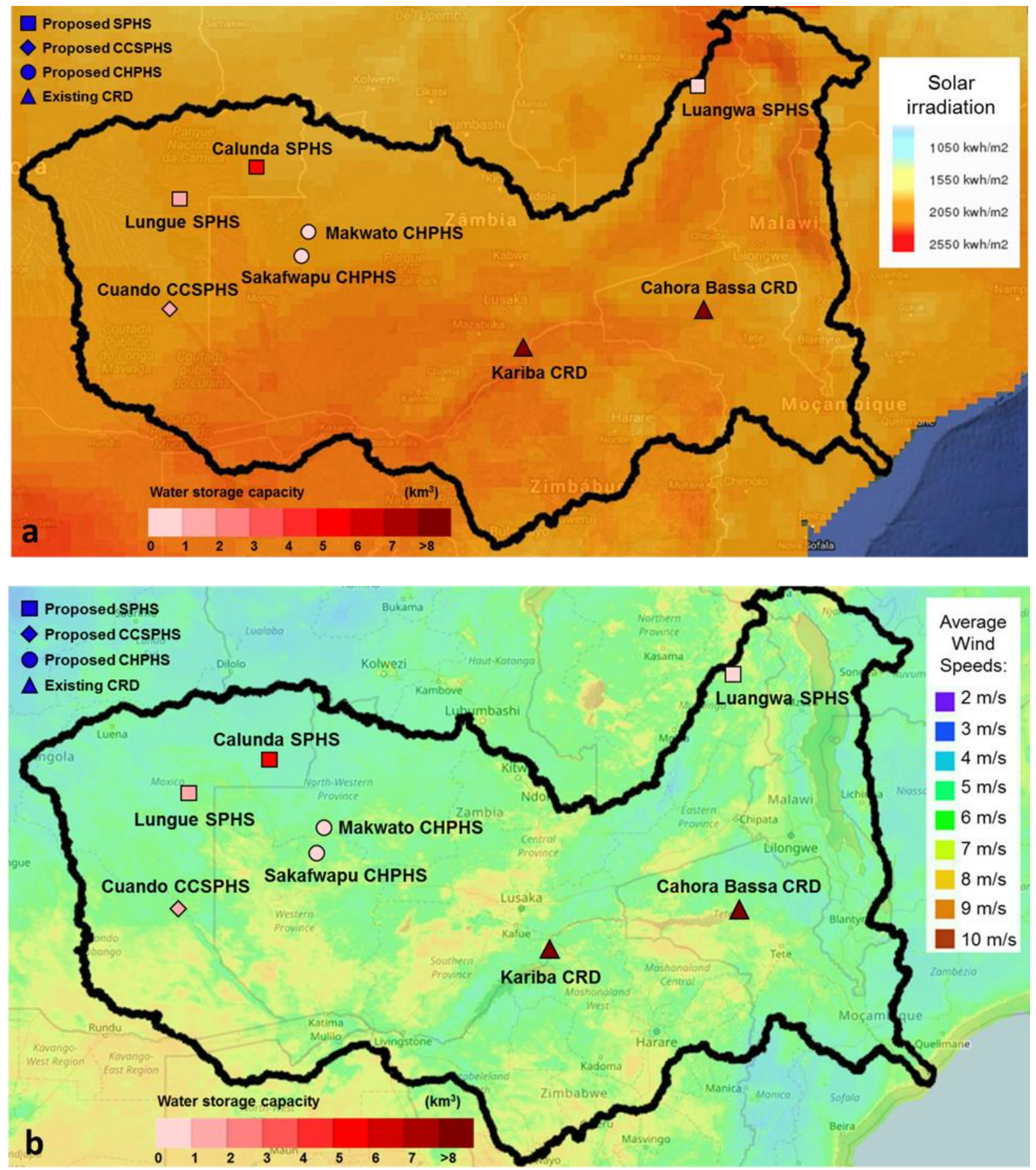

Figure 9: Zambezi basin (a) solar generation potential [71], (b) and wind generation potential

A cost comparison between some of the proposed PHS projects and the compatible

424 conventional reservoir dam for water storage is presented in Figure 10. According to the

425 results, the water storage costs for the Cuando CRD reservoir is more expensive than the

426 Cuando CCSPHS plant with 103 MW and 600 MW. This is mainly because, the Cuando 
427 CRD would require a large area to store water, which would result in large land costs and

428 losses due to evaporation. Water storage costs are used for the comparison because the

429 electricity generated by the Cuando CRD plant is considerably small and water is a major

430 issue in the region. The Cuando CCSPHS project with $600 \mathrm{MW}$ would be more beneficial

431 than the Cuando CCSPHS with $103 \mathrm{MW}$ because the turbine would be used both to store

432 energy and water, benefiting from both revenues.

However, for the other proposed plants (Makwato, Calunda and Sakafwapu), the CRD

434 alternative is cheaper than the PHS alternatives. This is mainly because, hydropower in the

435 Upper Zambezi region has low viability to justify a CHPHS project due to the low head, and

436 furthermore, the Calunda SPHS plant requires a $23 \mathrm{~km}$ tunnel, which considerably increases

437 the costs of the project. Figure 11 presents a representation of the Cuando CCSPHS and

438 Makwato CHPHS projects.

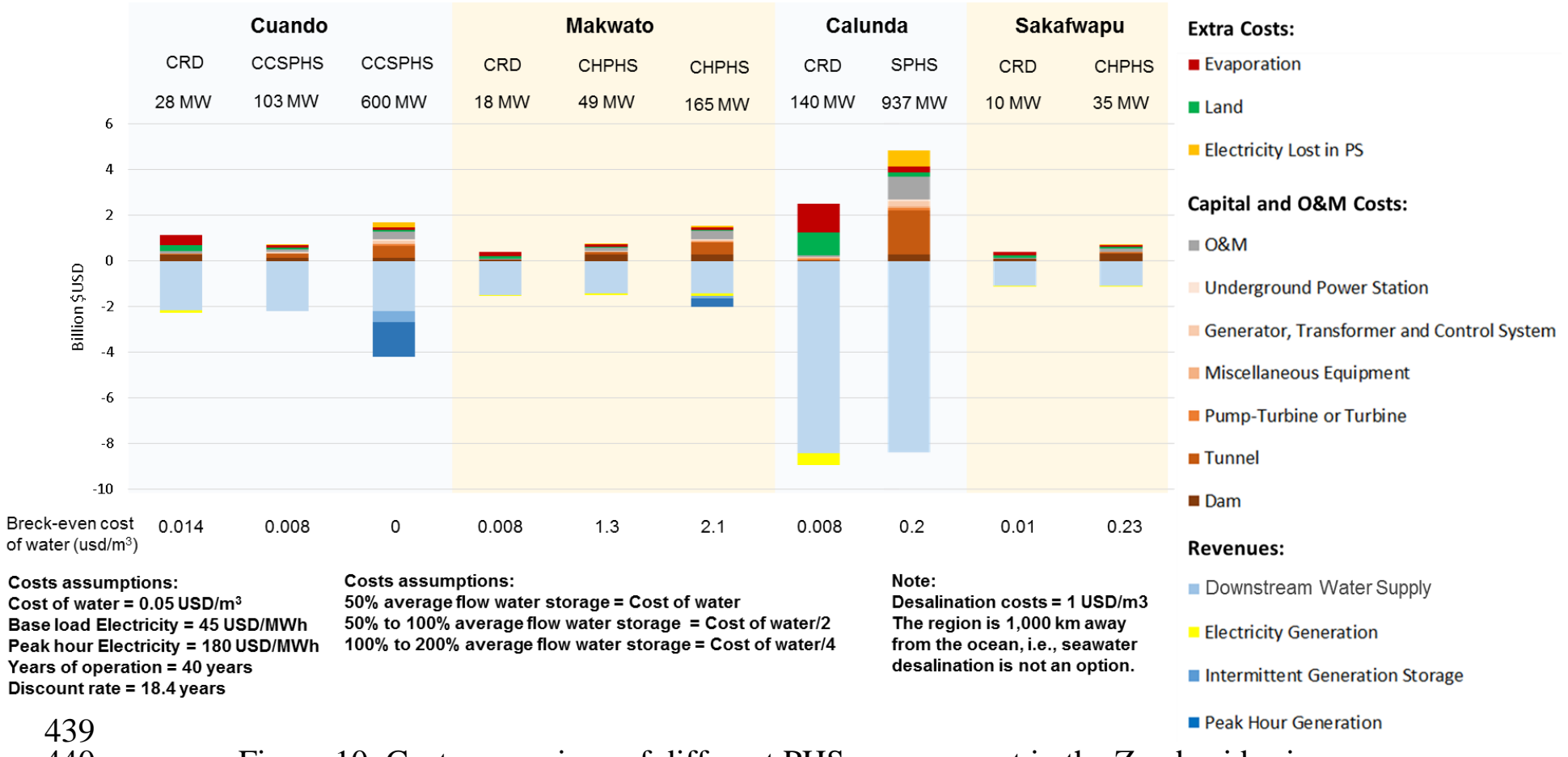

440

Figure 10: Cost comparison of different PHS arrangement in the Zambezi basin. 

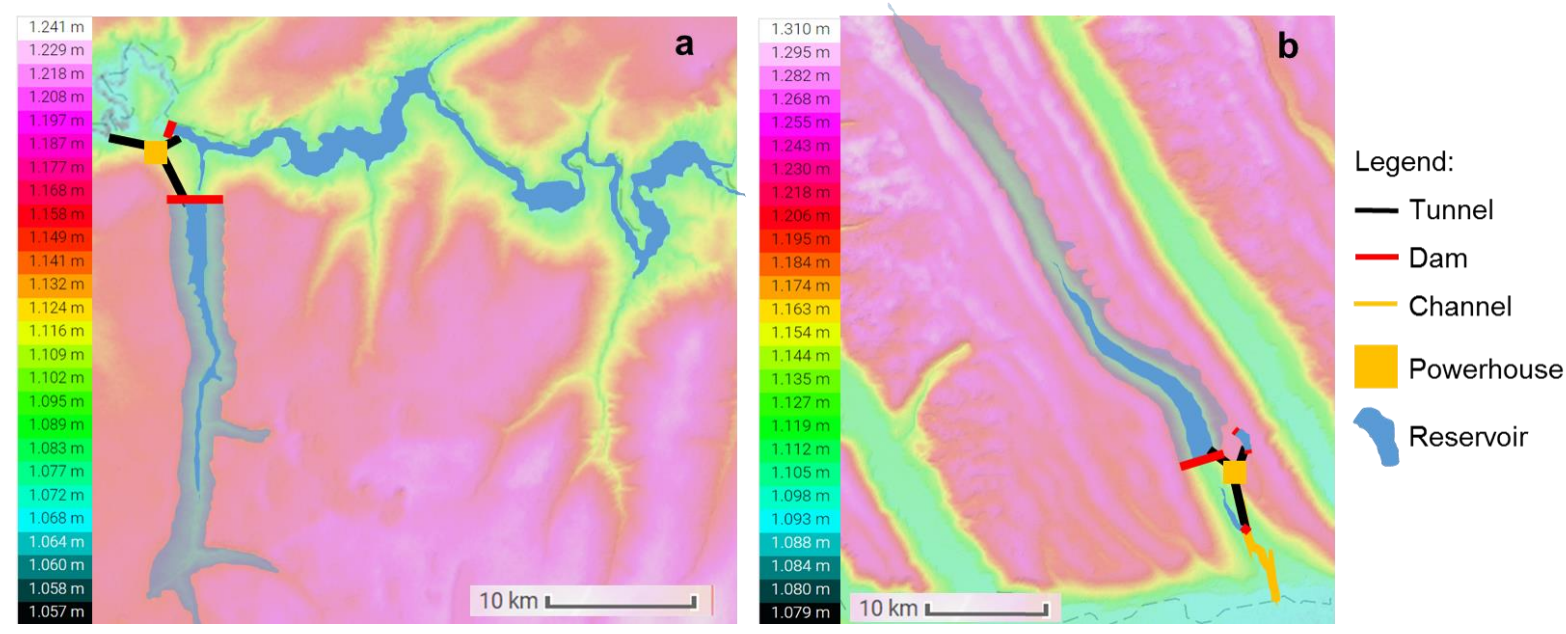

Figure 11: Representation of proposed (a) Makwato CHPHS and (b) Cuando CCSPHS.

This case study intends to support the sustainable development of the region and

intended to regulate the river flow at their sub-basin level, reduce water storage evaporation, reduce the intensity of floods, store water in case of droughts and store electricity from intermittent generation sources.

\section{Discussion}

There is a variety of alternatives to implement PHS arrangements for short and longterm energy and water storage. Comparing the proposed PHS arrangements in this paper demonstrates the benefits and drawbacks of each approach. It is important to examine different possibilities of building SPHS by a quantitative method, such as the one proposed in this paper, to identify the most feasible and useful projects to be developed in any given topography and hydrology, and for meeting the needs for energy and water storage. Table 7 summarizes the benefits and drawbacks of the main arrangements discussed in this paper. 


\begin{tabular}{|c|c|c|}
\hline Technology & Benefits & Drawbacks \\
\hline $\begin{array}{c}\text { Pump-Back } \\
\text { Storage (PBHS) }\end{array}$ & $\begin{array}{l}\text { - Good alternative for building dams in } \\
\text { cascade, combining hydropower } \\
\text { generation, short and long-term storage. } \\
\text { - More operation flexibility. } \\
\text { - Cheap alternative, if the dams are already } \\
\text { planned to be built. }\end{array}$ & $\begin{array}{l}\text { - Need for damming the main river. } \\
\text { - Storing water in a main river causes large socio- } \\
\text { environmental and economic impacts. } \\
\text { - Difficulties in retrofitting existing dams to PHS } \\
\text { due to the need for large tunnels with low head. }\end{array}$ \\
\hline $\begin{array}{c}\text { Seasonal } \\
\text { Pumped- } \\
\text { Storage (SPHS) }\end{array}$ & $\begin{array}{l}\text { - Large flexibility for the operation of the } \\
\text { SPHS plant, including seasonal, weekly } \\
\text { and daily cycles. } \\
\text { - A storage reservoir built on a tributary } \\
\text { river has lower environmental and social } \\
\text { impacts, than one built on the main river. } \\
\text { This is because the surrounding of main } \\
\text { rivers usually have higher population } \\
\text { concentration and higher importance to } \\
\text { the environment. }\end{array}$ & $\begin{array}{l}\text { - Need for damming the main river. However, } \\
\text { existing dams may be used as a lower reservoir }\end{array}$ \\
\hline $\begin{array}{l}\text { Run-of-the-River } \\
\text { Pumped-Storage } \\
\text { (RRPHS) }\end{array}$ & - No need to dam the main river. & $\begin{array}{l}\text { - Due to the direct influence of the SPHS operation } \\
\text { in the main river flow, the operation is limited to } \\
\text { seasonal cycles. Daily storage cycles would have } \\
\text { a great impact on the main river flow, which is } \\
\text { not advisable. This could be resolved by building } \\
\text { another pump-turbine circuit between the river } \\
\text { and a lower reservoir off the main river. }\end{array}$ \\
\hline $\begin{array}{l}\text { Combined } \\
\text { Cycles Seasonal } \\
\text { Pumped- } \\
\text { Storage } \\
\text { (CCSPHS) }\end{array}$ & $\begin{array}{l}\text { - Increases the possibility of building large } \\
\text { reservoirs for energy and water storage. } \\
\text { Particularly in regions with low } \\
\text { topography. } \\
\text { - The high water level variation in the } \\
\text { reservoirs is appropriate to reduce } \\
\text { evaporation in arid regions. }\end{array}$ & $\begin{array}{l}\text { - In order to make this arrangement work, there is } \\
\text { the necessity of both short and long-term energy } \\
\text { storage needs. This reduces the flexibility of the } \\
\text { plant. For example, if there is no need for short- } \\
\text { term storage, the plant won't the able to fill up } \\
\text { the reservoir for long-term storage. }\end{array}$ \\
\hline $\begin{array}{l}\text { Combined } \\
\text { Hydropower } \\
\text { and Pumped- } \\
\text { Storage } \\
\text { (CHPHS) }\end{array}$ & $\begin{array}{l}\text { - Combine hydropower and pumped-storage } \\
\text { with the same pump/turbine. } \\
\text { - The proposal with two reservoirs does not } \\
\text { require excavation of the powerhouse. } \\
\text { - More reservoirs could be included to } \\
\text { increase the catchment area for } \\
\text { hydropower. } \\
\text { - It is possible to store large amounts of } \\
\text { water and energy. } \\
\text { - Increase the operational flexibility of the } \\
\text { pump-turbines, generating or storing } \\
\text { energy, which increases the capacity factor } \\
\text { of the reversible pump-turbines, sub- } \\
\text { stations, transmission lines, among others. }\end{array}$ & $\begin{array}{l}\text { - There is a need for damming the main river. } \\
\text { - Given to the need to combine hydropower and } \\
\text { storage, there are less locations where this would } \\
\text { be possible to build. } \\
\text { - Low head projects are only feasible with very } \\
\text { short tunnel lengths. }\end{array}$ \\
\hline
\end{tabular}




\section{Conclusions}

461

462

463

464

465

466

467

468

469

470

471

472

473

474

475

476

477

478

479

480

481

482

483

484

This paper presented and exemplified different types of PHS plants, focusing on plants with large reservoirs for water and energy storage, the so called, seasonal pumpedhydro storage. The cost reduction of battery energy storage technologies will challenge the feasibility and competitiveness of short-term storage PHS plants. Hence, this paper suggests that future PHS projects should serve both short and long-term energy storage needs, and water storage.

The proposed PHS methods and configurations in this article have the main objective to increase the possibilities of building large reservoirs in parallel to a main river while reducing the socio-economic and environmental impacts of conventional reservoir dams. The CCSPHS arrangement proved to be particularly feasible for locations with low topography and limited sites for large storage reservoirs. The CHPHS plant increases the operational flexibility of the plant generating electricity when the flow of the river is high and stores energy when the river flow is low, increasing the viability of the plant.

Comparing the costs of water storage with Cuando CRD for $0.014 \$ / \mathrm{m}^{3}$ and with Cuando CCSPHS for $0.008 \$ / \mathrm{m}^{3}$, the case study in the Zambezi region shows that the only arrangement that was proven competitive to conventional reservoir dams is the CCSPHS plant. Adding the need for short-term energy storage, the costs of water storage reduces to 0 $\$ / \mathrm{m}^{3}$, as the energy storage need would cover the total costs of the project. CCSPHS is a configuration designed for storing large amount of energy and water in regions with low topography where considerable evaporation losses could occur in conventional reservoir dams. Even though the new proposed arrangements in this paper increases the viability of some PHS projects, the topography will remain the main decision driver for future PHS projects. 

and long-term storage. PHS will become even more important as it can improve resource management and security of supply in the energy and water sectors. Thus, the identification of new arrangements for PHS might enhance the socio, economic and ecological viability of this technology, hence, contributing to the development of a sustainable future.

490

\section{Acknowledgements}

492

493

We would like to thank the CAPES/Brazil for the research grant and IIASA for the 494 postdoctoral research fellowship.

495

\section{References}

497

498

[1] Griggs D, Stafford-Smith M, Gaffney O, Rockström J, Öhman MC, Shyamsundar P, et al. Policy: Sustainable development goals for people and planet. Nature 2013;495:3057. doi:10.1038/495305a.

[2] Rasul G, Sharma B. The nexus approach to water-energy-food security: an option for adaptation to climate change. Clim Policy 2016;16:682-702. doi:10.1080/14693062.2015.1029865.

[3] Ringler C, Bhaduri A, Lawford R. The nexus across water, energy, land and food (WELF): Potential for improved resource use efficiency? Curr Opin Environ Sustain 2013;5:617-24. doi:10.1016/j.cosust.2013.11.002.

[4] Huertas-Hernando D, Farahmand H, Holttinen H, Kiviluoma J, Rinne E, Söder L, et al. Hydro power flexibility for power systems with variable renewable energy sources: an IEA Task 25 collaboration. Wiley Interdiscip Rev Energy Environ 2017;6:e220. doi:10.1002/wene.220.

5] Schill W-P, Zerrahn A. Long-run power storage requirements for high shares of renewables: Results and sensitivities. Renew Sustain Energy Rev 2018;83:156-71. 
doi:https://doi.org/10.1016/j.rser.2017.05.205.

514 [6] Kougias I, Szabó S. Pumped hydroelectric storage utilization assessment : Forerunner of renewable energy integration or Trojan horse? 2017;140:318-29. doi:10.1016/j.energy.2017.08.106.

517 [7] NHA. Challenges and Opportunities For New Pumped Storage Development: A White Paper Developed by NHA’s Pumped Storage Development Council. 2017.

[8] International Hydropower Association. Pumped Storage Tracking Tool 2019.

[9] Hunt J, Byers E, Riahi K, Langan S. Comparison between seasonal pumped-storage and conventional reservoir dams from the water, energy and land nexus perspective. Energy Convers Manag 2018;166:385-401.

[10] International Hydropower Association. Map of world hydropower 2019. https://www.hydropower.org/maps/worldhydropowerstatistics.

[11] Kathan J, Esterl T, Leimgruber F, Helfried B. Pumpspeicher Römerland. 2012.

[12] Weber A, Beckers T, Feuß S, von Hirschhausen C, Hoffrichter A, Weber D. Potentiale zur Erzielung von Deckungsbeiträ- gen für Pumpspeicherkraftwerke in der Schweiz, Österreich und Deutschland. Berlin: 2014.

[13] Ehteram M, Allawi MF, Karami H, Mousavi S-F, Emami M, EL-Shafie A, et al. Optimization of Chain-Reservoirs' Operation with a New Approach in Artificial Intelligence. Water Resour Manag 2017;31:2085-104. doi:10.1007/s11269-017-16256.

[14] Wagner B, Hauer C, Schoder A, Habersack H. A review of hydropower in Austria:

[15] Torres O. Life cycle assessment of a pumped storage power plant. Trondheim: 2011.

[16] Solvang E, Charmasson J, Sauterlaute J, Harby A, Killingtveit Å, Egeland H, et al. Norwegian hydropower for large scale electricity balancing needs - Pilot study of technical, environmental and social challenges. Trondheim: 2014.

[17] Verband Schweizerischer Elektrizitatsunternehmen. Die Rolle der Pumpspeicher in der Elektrizitätsversorgung. 2013.

[18] Geisseler VL, Vogel S. Die Geschichte der Schweizer Wasserkraft. Gewässerkunde, vol. 662, Bern: Geogräphisches Institut, Universität Bern; 2016.

[19] Pfammatter R, Piot M. Situation und Perspektiven der Schweizer Wasserkraft. Baden: 2014. 
[20] Glauser H. Pumpspeicherung, CO2 und Wirtschaftlichkeit: am Beispiel der Kraftwerke Oberhasli. Zurich: 2004.

[21] Pérez-Díaz JI, Sarasúa JI, Wilhelmi JR. Contribution of a hydraulic short-circuit pumped-storage power plant to the load-frequency regulation of an isolated power system. Int J Electr Power Energy Syst 2014;62:199-211.

doi:https://doi.org/10.1016/j.ijepes.2014.04.042.

[22] Goekler G, Meusburger P. Austria's Kops II on the grid: First experiences and lessons learned 2009;16:70-4.

[23] Rehman S, Al-Hadhrami LM, Alam MM. Pumped hydro energy storage system: A technological review. Renew Sustain Energy Rev 2015;44:586-98. doi:10.1016/j.rser.2014.12.040.

[24] Hassa R, Bogenrieder W. The new pumped-storage power station at Goldisthal. VGB PowerTech 2004;84:24-30+6.

[25] Bravo JC, Gaztañaga JM. The design of Spain's la Muela II pumped-storage plant. Int J Hydropower Dams 2012;19:39-42.

[26] Gür TM. Review of electrical energy storage technologies, materials and systems: Challenges and prospects for large-scale grid storage. Energy Environ Sci 2018;11:2696-767. doi:10.1039/c8ee01419a.

[27] Caralis G, Christakopoulos T, Karellas S, Gao Z. Analysis of energy storage systems to exploit wind energy curtailment in Crete. Renew Sustain Energy Rev 2019:122-39. doi:10.1016/j.rser.2018.12.017.

[28] Melikoglu M. Pumped hydroelectric energy storage: Analysing global development and assessing potential applications in Turkey based on Vision 2023 hydroelectricity wind and solar energy targets. Renew Sustain Energy Rev 2017;72:146-53. doi:10.1016/j.rser.2017.01.060.

[29] Kerr J. Usinas reversíveis e outros elementos especiais de sistemas de reservatórios. IV Semin. Nac. Produção e Transm. Energ. Elétrica, 1977, p. 1-32.

[30] Bocquel A, Janning J. Analysis of a $300 \mathrm{MW}$ variable speed drive for pump-storage plant applications, 2005, p. 10 pp.-P.10. doi:10.1109/EPE.2005.219434.

[31] VOITH. Pumped storage machines: Reversible pump turbines, Ternary sets and Motor-generators. 2011.

[32] Yang W, Yang J. Advantage of variable-speed pumped storage plants for mitigating wind power variations: Integrated modelling and performance assessment. Appl Energy 2019;237:720-32. doi:https://doi.org/10.1016/j.apenergy.2018.12.090. 
[33] Sivakumar N, Das D, Padhy NP. Variable speed operation of reversible pump-turbines at Kadamparai pumped storage plant - A case study. Energy Convers Manag 2014;78:96-104. doi:10.1016/j.enconman.2013.10.048.

[34] Ciocan G, Teller O, Czerwinski F. Variable speed pump-turbines technology. UPB Sci Bull Ser D Mech Eng 2012;74:33-42.

[35] Marriott M. Nalluri And Featherstone's Civil Engineering Hydraulics: Essential Theory with Worked Examples. Oxford: Wiley-Blackwell; 2016.

[36] Henry J, Maurer F, Drommi J, Sautereau T. Converting to variable speed at a pumpedstorage plant. 2013.

[37] Datry T, Boulton A, Bonada N, Fritz K, Leigh C, Sauquet E, et al. Flow intermittence and ecosystem services in rivers of the Anthropocene. J Appl Ecol 2017:1-12.

[38] Snowy Mountains Hydro-Electric Authority. The Snowy Mountains Scheme: A National Engineering Landmark. Talbingo: Minister for Resources; 1990.

[39] US Army Corps of Engineers. Columbia River \& Tributaies Pacific Northwest Regional Pumped-Storage Study. 1980.

[40] Central Arizona Project. 2013 Annual Water Quality Report. Phoenix: 2014.

[41] Lonnecker B. Generator/motors and adjustable-speed drives for Waddell pumpedstorage plant. Proc. Int. Conf. Hydropower, Portland: 1987.

[42] Fitzgerald JP. Operation of seneca pumped storage plant. IEEE Trans Power Appar Syst 1973;PAS-92:1510-6. doi:10.1109/TPAS.1973.293695.

[43] Blakers A, Lu B, Stocks M. 100\% renewable electricity in Australia. Energy 2017;133:471-82. doi:10.1016/j.energy.2017.05.168.

[44] Chazarra M, Pérez-Díaz JI, García-González J. Deriving optimal end of day storage for pumped-storage power plants in the joint energy and reserve day-ahead scheduling. Energies 2017;10. doi:10.3390/en10060813.

[45] Northland Power. Marmora Pumped Storage 2018.

[46] Nadler H. Hydropower pump-back projects/perspectives. Southwest. Fed. Hydropower Conf., Tulsa, Oklahoma: n.d.

[47] Deane JP, Gallachóir BPÓ, McKeogh EJ. Techno-economic review of existing and new pumped hydro energy storage plant. Renew Sustain Energy Rev 2010;14:1293302. doi:https://doi.org/10.1016/j.rser.2009.11.015.

[48] Peltier R. Kannagawa hydropower plant, Japan. Power 2006;150:54-8.

[49] Bueno C, Carta JA. Wind powered pumped hydro storage systems, a means of increasing the penetration of renewable energy in the Canary Islands. Renew Sustain 
Energy Rev 2006;10:312-40. doi:10.1016/j.rser.2004.09.005.

[50] Portero U, Velázquez S, Carta JA. Sizing of a wind-hydro system using a reversible hydraulic facility with seawater. A case study in the Canary Islands. Energy Convers Manag 2015;106:1251-63. doi:10.1016/j.enconman.2015.10.054.

[51] Winde F, Kaiser F, Erasmus E. Exploring the use of deep level gold mines in South Africa for underground pumped hydroelectric energy storage schemes. Renew Sustain Energy Rev 2017;78:668-82. doi:10.1016/j.rser.2017.04.116.

[52] Menéndez J, Loredo J, Galdo M, Fernández-Oro JM. Energy storage in underground coal mines in NW Spain: Assessment of an underground lower water reservoir and preliminary energy balance. Renew Energy 2019;134:1381-91. doi:10.1016/j.renene.2018.09.042.

[53] Pujades E, Jurado A, Orban P, Dassargues A. Parametric assessment of hydrochemical changes associated to underground pumped hydropower storage. Sci Total Environ 2019;659:599-611. doi:10.1016/j.scitotenv.2018.12.103.

[54] Matos CR, Carneiro JF, Silva PP. Overview of Large-Scale Underground Energy Storage Technologies for Integration of Renewable Energies and Criteria for Reservoir Identification. J Energy Storage 2019;21:241-58. doi:10.1016/j.est.2018.11.023.

[55] Pujades E, Orban P, Bodeux S, Archambeau P, Erpicum S, Dassargues A. Underground pumped storage hydropower plants using open pit mines: How do groundwater exchanges influence the efficiency? Appl Energy 2017;190:135-46. doi:10.1016/j.apenergy.2016.12.093.

[56] Pujades E, Willems T, Bodeux S, Orban P, Dassargues A. Underground pumped storage hydroelectricity using abandoned works (deep mines or open pits) and the impact on groundwater flow [Hydroélectricité par pompage-turbinage en utilisant des excavations souterraines abandonnées (mines profondes ou carrières) et . Hydrogeol J 2016;24:1531-46. doi:10.1007/s10040-016-1413-z.

[57] Ghorbani N, Makian H, Breyer C. A GIS-based method to identify potential sites for pumped hydro energy storage - Case of Iran. Energy 2019;169:854-67. doi:10.1016/j.energy.2018.12.073.

[58] Ioakimidis CS, Genikomsakis KN. Integration of seawater pumped-storage in the energy system of the Island of São Miguel (Azores). Sustain 2018;10. doi:10.3390/su10103438.

[59] Albadi MH, Al-Busaidi AS, El-Saadany EF. Seawater PHES to facilitate wind power integration in dry coastal areas - Duqm case study. Int J Renew Energy Res 
2017;7:1363-75.

[60] Berrada A, Loudiyi K, Zorkani I. System design and economic performance of gravity energy storage. J Clean Prod 2017;156:317-26. doi:https://doi.org/10.1016/j.jclepro.2017.04.043.

[61] Heindl-Energy. Gravity Storage 2019.

[62] Puchta M, Bard J, Dick C, Hau D, Krautkremer B, Thalemann F, et al. Development and testing of a novel offshore pumped storage concept for storing energy at seaStensea. J Energy Storage 2017;14:271-5. doi:https://doi.org/10.1016/j.est.2017.06.004.

[63] Grumet T. This Unique Combo Of Wind And Hydro Power Could Revolutionize Renewable Energy. GE Reports 2016.

[64] Grill G, Lehner B, Lumsdon A, MacDonald G, Zarfl C, Liermann C. An index-based framework for assessing patterns and trends in river fragmentation and flow regulation by global dams at multiple scales. Environ Res Lett 2015;10.

[65] Slapgard J. Cost base for hydropower plants. Oslo: 2012.

[66] Information C-C for S. SRTM 90m Digital Elevation Data 2017.

[67] Wada Y, Graaf I, van Beek L. High-resolution modeling of human and climate impacts on global water resources. J Adv Model Earth Syst 2016;8:735-63.

[68] Rognlien L. Pumped Storage Development in Ovre. Otra, Norway: 2012.

[69] Hunt J, Byers E, Wada Y, Parkinson S, Gernaat D, Langan S, et al. Global resource potential of seasonal pumped-storage for energy and water storage. Nat Commun 2019;PRE-PRINT.

[70] Beilfuss R. A Risky Climate for Southern African Hydro: Assessing Hydrological Risks and Consequences for Zambezi River Basin Dams. Berkeley: 2012.

[71] IRENA. Global Solar Map (GHI) by Meteotest. Glob Atlas Renew Energy 2017.

[72] IRENA. DTU Global Wind Atlas 1km Resolution. Glob Atlas Renew Energy 2017.

[73] Jacobson M, Delucchi M, Cameron M, Frew B. Low-cost solution to the grid reliability problem with $100 \%$ penetration of intermittent wind, water, and solar for all purposes. Proc Natl Acad Sci United States Am PNAS, Proc Natl Acad Sci 2015;112:15060-5. 